\title{
APLIKASI TEKNIK GRAFTING PADA PEMBIBITAN DURIAN KUNYIT INDIKASI GEOGRAFIS PUPUAN TABANAN
}

\author{
S.M. Sarwadana ${ }^{1}$, N.L.M. Pradnyawathi ${ }^{2}$, dan N.N. Darmiati ${ }^{3}$
}

\begin{abstract}
ABSTRAK
Kegiatan IbKIK bertujuan: (1) komersialisasi Ipteks kreativitas kampus sebagai sumber pembiayaan untuk pengebangan institusi; (2) memacu jiwa kewirausahaan dikalangan insan kampus, dan (3) membantu masyarakat mendapatkan bibit varietas Durian Kunyit. Metode pelaksanaan meliputi aspek bisnis rencana usaha kegiatan yang terdiri dari: bahan baku, produksi, proses produksi, manajemen, pemasaran, sumberdaya manusia, fasilitas, dan financial. Bahan baku diperoleh dari unit IbKIKK dan melalui kemitraan dengan petani penangkar bibit Durian Kunyit. Produk yang dihasilkan berupa bibit Durian kunyit unggul dengan produktivitas di atas 60-70 biji /pohon, kapasitas produksi 1000 pohon pada tahun pertama dan meningkat $100 \%$ pada tahun berikutnya. Proses produksi dimulai dari penyemaian batang bawah, penyambungan (grafting) batang bawah dengan batang atas, dan pemeliharaan. Manajemen IbKIK dilakukan oleh tim yang berada dibawah program studi agroekoteknologi Fakultas Pertanian. Pemasaran dilakukan secara langsung, kemitraan dengan Pemda dan konsiniasi dengan kios/toko pertanian. Sumberdaya manusia yang terlibat terdiri dari : 1 orang ketua, tiga kepala bidang, satu tenaga administrasi, dan 2 orang tenaga kerja operasional. Fasilitas yang tersedia berupa lahan kebun bibit seluas $1000 \mathrm{~m} 2$, ruang kantor dan nursery $100 \mathrm{~m} 2$.
\end{abstract}

Kata Kunci : teknik grafting, aplikasi, pembibitan, durian kunyit, indikasi geografis.

\begin{abstract}
IbKIK's activities are aimed at: (1) the commercialization of the campus creativity sciences as a source of financing for institutional felling; (2) spur the entrepreneurial spirit among campus people, and (3) help the community to get the varieties of Durian Kunyit seedlings. Methods of implementation include business aspects of business plan activities consisting of: raw materials, production, production process, management, marketing, human resources, facilities, and financial. The raw material is obtained from Ibkikk unit and through partnership with farmer breeder of Durian Kunyit seedlings. The resulting product is Durian superior turmeric seeds with productivity above 60-70 seeds / tree, production capacity of 1000 trees in the first year and $100 \%$ increase in the next year. Production process starts from seeding rootstock, grafting of rootstock with stem, and maintenance. IbKIK Management is conducted by a team under the agroecotechnology study program of Faculty of Agriculture. Marketing is done directly, partnerships with local government and consignment with kiosks / farm shops. The human resources involved consist of: 1 chairman, three heads of administration, one administrative staff, and 2 operational manpower. The available facilities are $1000 \mathrm{~m} 2$ of nursery, office space and $100 \mathrm{~m} 2$ nursery.
\end{abstract}

Key words : grafting, application, nurseries, durian, geographic indication.

\footnotetext{
${ }^{1}$ Staf Pengajar Fakultas Pertanian Universitas Udayana, sarwadana55@unud.ac.id

${ }^{2,3}$ Staf Pengajar Fakultas Pertanian Universitas Udayana
} 


\section{PENDAHULUAN}

Durian Kunyit adalah salah satu varietas durian lokal yang sangat digemari oleh penikmat durian di Bali, bahkan oleh wisatawan yang datang ke Bali. Tanaman ini endemik tumbuh di kawasan Kecamatan Pupuan Kabupaten Tabanan dan tidak dijumpai di wilayah lainnya di Bali. Nama Durian Kunyit merupakan sebutan yang diberikan oleh masyarakat karena warna daging buahnya yang kuning bening seperti warna rimpang kunyit. Karakteristik buah "Durian Kunyit" adalah sebagai berikut : buah yang berbentuk bulat telur dengan warna hijau kekuningan. Duri kulitnya berbentuk kerucut kecil dan rapat. Buahnya berukuran sebesar kelapa gading dengan penampilan sangat menarik dengan bobot buah $1-2^{1 / 2} \mathrm{~kg}$. Daging buah agak tebal, berlemak, bertekstur agak lembek, berserat halus, beraroma sedang atau tidak begitu tajam. Keunggulan "Durian Kunyit " dibandingkan dengan varietas durian yang umum di Bali seperti : durian Bestala, durian montong, durian kane dan lain-lain, yaitu rasanya yang khas tidak terlalu manis, gurih, lembut, dan baunya yang tidak menyengat. Oleh sebab itu, durian kunyit menjadi buah-buahan paporit dan diburu oleh pedagang dan penikmat durian baik masyarakat lokal, maupun manca negara yang berwisata ke wilayah Pupuan.

Persoalan yang dijumpai di lapangan adalah semakin terbatasnya populasi tanaman Durian Kunyit. Hasil inventariasasi yang dilakukan oleh tim peneliti Fakultas Pertanian Universitas Udayana pada tahun 2013-2014 melalui Hibah MP3EI dan Hibah Daerah menunjukkan bahwa di seluruh Kecamatan Pupuan populasi durian kunyit hanya mencapai 50 pohon. Bahkan pohon yang masih produktif, tidak lebih dari 15 pohon yang terdapat di Desa Belimbing. Kelangkaan tanaman durian tersebut terjadi karena tanaman durian kunyit umumnya tumbuh sendiri, bukan hasil budidaya atau penanaman. Usaha penanaman sudah banyak dilakukan oleh masyarakat melalui perbanyakan melalui biji buah (generatif), tetapi hasil yang dieroleh kurang memuaskan karena tanaman baru yang dihasilkan tidak sama dengan karakteristik induknya. Selain itu, waktu produksi yang terlalu lama yaitu mencapai 10 tahun juga menjadi penyebab peningkatan populasi tanaman tersebut. Karena banyak pohon durian kunyit yang sudah tua dan tidak produktif lagi, maka populasinya semakin menyusut. Oleh sebab itu, untuk menjaga populasi durian kunyit dan pelestarian plasma nuftah unggul tersebut maka sangat diperlukan usaha pembibitan dengan aplikasi teknologi yang mampu menghasilkan tanaman hasil perbanyakan yang sama dengan induknya.

Hal tersebut di atas memperlihatkan akan pentingnya upaya untuk melakukan pembibitan/perbanyakan tanaman tersebut. Perbanyakan tanaman bertujuan untuk mendapatkan bibit unggul. Setidaknya bibit unggul (superior) tersebut harus memiliki karakter seperti pohon induknya. Teknologi yang dapat diaplikasikan untuk tujuan tersebut adalah teknik perbanyakan secara vegetatif (grafting). Teknik perbanyak secara grafting tersebut tidak menyebabkan perubahan kromosom pohon atau tanaman induknya. Teknik yang paling cocok diaplikasikan adalah teknik grafting, baik top grafting maupun side grafting. Aplikasi teknik grafting menunjukkan keberhasilangrafting tersebut tidak menyebabkan perubahan kromosom pohon atau tanaman induknya. Teknik yang paling cocok diaplikasikan adalah teknik grafting, baik top grafting maupun side grafting. Aplikasi teknik grafting menunjukkan keberhasilan yang sangat tinggi, yaitu rata-rata mencapai $80 \%$. Model perbanyakan grafting atau sambung merupakan gabungan dari 2 tanaman yang selanjutnya tumbuh menjadi satu tanaman 
(Edmond et al.,1981; Gardner dan Chaudhri, 1976). Tanam pohon disebut batang yang berperan sebagai akar dinamakan batang bawah dan tanaman yang perannya sebagai pohon dinamakan batang atas. System grafting menghasilkan bibit yang sama dengan karakter positif dari pohon induknya, serta menghasilkan tanaman yang berbuah dalam waktu yang lebih cepat dibandingkan dengan teknik generatif (biji). Untuk tanaman Durian , teknik grafting tanaman berbuah sesudah 4-5 tahun dengan batang bawah yang digunakan masih berumur muda ( 3 - 7 bulan) dengan ukuran diameter tanan sekitar 0.5 hingga $1 \mathrm{~cm}$, sedangkan untuk perbanyakan dengan biji tanaman baru berbuah sesudah 10 tahun atau lebih.

Kepopuleran "Durian Kunyit" mendorong pemerintah Kabupaten Tabanan mengembangkan kawasan agrowisata dengan menjadikan "Durian Kunyit " sebagai ikon. Kawasan agrowisata tersebut berlokasi di wilayah Desa Sanda Kecamatan Pupuan dengan menempati lahan seluas 18 ha. Program tersebut memerlukan bibit durian yang cukup banyak, selain untuk pengembangan tanaman tersebut di lahan- lahan masyarakat. Dalam rangka pengadaan bibit tersebut, Pemda Tabanan telah menjalin kerjasama dengan Fakultas Pertanian Universitas Udayana yang realisasinya mulai tahun 2017. Selain untuk keperluan program tersebut, tanaman ini juga potensial dikembangkan pada lahan-lahan dengan kondisi agroekosistem yang mirip di Propinsi Bali yang dengan luas lahan mencapai 4.855,9 hektar. Bila diasumsikan keperluan bibit sebanyak 100 pohon per hektar maka akan diperluakan sebanyak 48.559 pohon.

Durian Kunyit merupakan jenis durian yang spesifik, tumbuh di wilayah Kecamatan Pupuan kabupaten Tabanan dengan populasi yang sangat sedikit. Komoditas ini potensial didaftarkan sebagai indikasi geografis. Sejauh ini, belum ada upaya untuk membibitkan tanaman tersebut secara komersial. Pembibitan terbatas dilakukan oleh masyarakat secara generatif (biji buah) yang potensial menghasilkan tanaman yang memiliki sifat berbeda dengan induknya. Sementara itu, kebutuhan bibit durian kunyit yang identik dengan induk sebagai buah unggulan Kabupaten Tabanan khususnya untuk mendukung program agrowisata oleh Pemda Kabupaten Tabanan sangat banyak. Memperhatikan nilai strategis dari bibit tanaman "Durian Kunyit" tersebut mendorong munculnya pemikiran menjadikan usaha Pembibitan Durian Kunyit sebagai Unit Ipteks bagi Kreativitas dan Inovasi Kampus (IbKIK) di Program Studi Agroekoteknologi Fakultas Pertanian Universitas Udayana. Usaha yang memproduksi Bibit Durian Kunyit tersebut merupakan usaha satusatunya sehingga belum memiliki kompetitor di pasaran. Produk bibit ini memiliki peluang pasar yang sangat besar, tidak saja di Kabupaten Tabanan tetapi juga di wilayah lain di Propinsi Bali bahkan di Indonesia. Peluang pasar produk ini terutama untuk memenuhi kebutuhan pesanan Pemda Kabupaten Tabanan untuk keperluan pengembangan agrowisata di kawasan pupuan berjumlah 5.000 pohon.

Pengembangan unit IbKIK tersebut akan dapat menjadi sarana untuk komersialisasi Ipteks hasil pengembangan perguruan tinggi, tempat pengembangan kewirausahaan berbasis Iptek (technopreneuship) bagi dosen dan mahasiswa, sumber pendapatan bagi institusi serta mendukung program nasional penggalakan buah lokal dalam rangka menekan konsumsi produk inport khususnya pada produk buah-buahan. Selain itu, pembibitan Durian Kunyit akan dapat sebagai wahana pelestarian plasma nutfah buah-buahan lokal khas Kecamatan Pupuan, Kabupaten Tabanan Bali. 


\section{METODE PELAKSANAAN}

Proses produksi bibit Durian Kunyit dimulai dari penyemaian entris bawah, koleksi entris atas, penyambungan entris bawah dan entris atas, pemeliharaan bibit melalui pemupukan dan penanggulangan hama dan penyakit, serta panen. Pada tahapan produksi bibit, ini dilakukan langkah-langkah sebagai berikut: Penyemaian entris bawah, koleksi pucuk (entris atas), penyambungan (grafting), penyungkupan, pemeliharaan, uji kualitas, dan pemasaran.

\section{HASIL DAN PEMBAHASAN}

Kegiatan yang dilakukan dalam pelaksanaan program IbKIK pembibitan durian kunyit diuraikan sebagai berikut:

1) Koleksi Induk Entris dan Batang Bawah

Koleksi Pohon induk entris diperoleh melalui survei dan seleksi dari tanaman durian kunyit yang tersebar di Kecamatan Pupuan Kabupaten Tabanan. Dari kegiatan surve yang dilanjutkan dengan seleksi tanaman yang memiliki sifat unggul maka diperoleh sebanya 5 pohon tanaman yang cocok dijadikan induk entris.

Duren kunyit diambil di Br. Dinas Duren taluh, Umur tanaman : \pm 15 th.

Batang tegak berwarna abu-abu, lingkar batang $122 \mathrm{~cm}$, tinggi tanaman $\pm 25 \mathrm{~m}$, cabang mendatar, cabang pertama pada ketinggian 4 meter, cabang selanjutnya pada ketinggian $9 \mathrm{~m}$.

Daun berbentuk oblongus/memanjang 4,5 x $13 \mathrm{~cm}$, ujung meruncing, pangkal membulat, permukaan atas hijau mengkilap, permukaan bawah abu-abu, seperti perkamen.

Batang bawah diambil dari perbanyakan dengan biji dari tanaman durian lokal dengan pohon kuat, umur 6 bulan, diameter batang $0,5-0,8 \mathrm{~cm}$, sehat.

2) Pembangunan balai seedling

Rumah seedling merupakan sarana yang sangat dibutuhkan pada usah pembibitan dengan metode grafting. Rumah seedling berfungsi menghindarkan bibit hasil grafting terkena air hujan. Entres dan batang bawah disambung untuk menghasilkan bibit durian kunyit yang berkualitas. Fase awal penyambungan tersebut, tanaman sangat rentan terhadap goyangan baik dari angin maupun air hujan yang berimplikasi terhadap kegagalan. Rumah seedling dibuat berukuran 3 x 4 berlokasi di Desa Belimbing Kabupaten Tabanan. Rumah seedling ini pada awalnya rumah seedling dibangun di kebun percobaan Fakultas Pertanian Universitas Udayana akan tetapi karena entris yang diambil dari pucuk pohon induk tidak bisa bertahan lama sebelum proses penyambungan. Oleh sebab itu, rumah seedling dipindah pembangunannya di lokasi yang berdekatan dengan pohon induk.

3) Balai Nurserry

Balai nurseri merupakan bangunan untuk merawat tanaman hasil grafting. Bibit tanaman hasil grafting yang sudah hidup, bila sudah tumbuh dengan baik selanjutnya dipindahkan ke balai seedling. Balai seedling terbuat dari tiang beton yang diberi atap paranet $60 \%$, berukuran 100 $\mathrm{m} 2$ pada lahan seluas $10000 \mathrm{~m} 2$. Lahan tersebut merupakan hasil sewa dari masyarakat (kelompok tani) di Desa Belimbing Kecamatan Pupuan Kabupaten Tabanan. Bibit dalam nurserry dirawat sebelum dijual, melalui pemupukan, pembersihan, dan penyiraman. Setelah bibit berumur enam bulan sudah siap dipasarkan. 
4) Penyiapan fasilitas, bahan, dan peralatan grafting

Fasilitas yang diperlukan pada kegiatan IbKIK pembibitan tanaman durian terdiri dari istalasi irigasi/penyiraman yaitu mesin pompa air, selang, dan springkel. Peralatan berupa electrikspryer untuk penyemprotan obat-obatan dan pestisida pencagah hama dan penyakit, cutter untuk memotong entris dan batang bawah, dan cutter khusus untuk tindakan grafting.

Bahan yang diperlukan meliputi tanah subur, pupuk organik, arang sekam dan sekam untuk media tanaman. Selain itu juga diperlukan ploybag, pupuk kimia NPK, pestisida, dan trichoderma untuk merangsang pertumbuhan perakaran.

5) Produksi Bibit

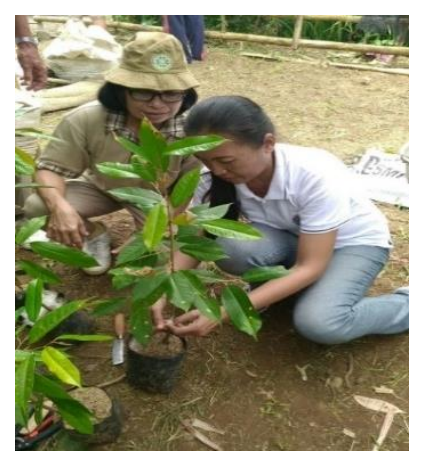

Target produksi bibit pada tahun 2017 sebanyak 1000 pohon. Target tersebut sudah berhasil dicapai pada bulan agustus 2017. Proses produksi melibatkan sebanyak empat tenaga kerja terdiri dari satu manajer produksi, satu tenaga memanjat untuk koleksi entris, dan dua orang tenaga grafting. Produksi diawali dengan pemupukan terhadap pohon durian yang akan dijadikan pohon induk sumber entris dengan jenis pupuk NPK. Setelah dua bulan pada tanaman induk akan tumbuh pucuk baru, setelah tiga bulan pucuk tersebut siap dipotong/dipanen untuk dijadikan entris.

\section{KESIMPULAN DAN SARAN}

Kesimpulan yang dapat diambil dari pelaksanaan kegiatan IbKIK Bibit Durian kunyit tahun 2017 adalah sebagai berikut:

1) Koleksi pohon induk sumber entris pada tahun 2017 berjumlah lima pohon

2) Sarana dan fasilitas yang berhasil disiapkan diantaranya : rumah seedling, kebun nurserry, dan peralatan serta bahan grafting dan pembibitan

3) Produksi bibit yang berhasil dihasilkan sampai akhir bulan agustus tahun 2017 sebanyak 1000 pohon.

Kegiatan lanjutan berupa penyiapan lokasi outlet pemasaran dan promosi produk kepada instansi pemerintah dan toko pertanian

\section{UCAPAN TERIMA KASIH}

Penulis mengucapkan terima kasih kepada KEMENRISTEK DIKTI atas dana yang diberikan lewat program IbIKK, Rektor Universitas Udayana, Ketua LPPM beserta staf terima kasih atas tenaga yang diberikan dalam pelaksanaan di lapangan, sehingga pengabdian kepada masyarakat terlaksana sesuai rencana.

\section{DAFTAR PUSTAKA}

Balai Statistik Propinsi Bali. 2012. Bali dalam Angka 2012. Balai Statistik Propinsi Bali Renon. Denpasar. Prastowo N, J.M. Roshetko. 2006.Tehnik Pembibitan dan Perbanyakan Vegetatif Tanaman Buah.World Agroforestry Centre (ICRAF) dan Winrock International. Bogor, Indonesia. p.100

Kantor Deputi Menegristek Bidang Pendayagunaan dan Pemasyarakatan Ilmu Pengetahuan dan Teknologi. 2000. Tentang Budidaya Pertanian Durian (Bombaceaesp). 